NOTE

\title{
Shedding and survival of an intracellular pathogenic Endozoicomonas-like organism infecting king scallop Pecten maximus
}

\author{
Patrick M. Hooper, Stuart H. Ross, Stephen W. Feist, Irene Cano* \\ International Centre of Excellence for Aquatic Animal Health, Cefas Weymouth Laboratory, Barrack Road, The Nothe, \\ Weymouth, Dorset DT4 8UB, UK
}

\begin{abstract}
The Lyme Bay marine protected area (MPA) hosts a valuable population of king scallop Pecten maximus L. Recently, an Endozoicomonas-like organism (ELO), infecting host gill epithelial tissue, was associated with king scallop mass mortality events within the Lyme Bay MPA. Currently, very little is known about its transmission and survival outside the host. In this investigation, animals collected outside of reported mortality events showed high levels of ELO infection. Gill tissue disruption and the release of bacteria into the interlamellar space was seen histologically, suggesting shedding of ELO from host animals. To investigate pathogen survival outside the host, infected scallops were maintained in static water for a $24 \mathrm{~h}$ period, and then removed. Over the subsequent $8 \mathrm{~d}$, water samples were collected and the quantity of ELO 16S rRNA transcript was measured by TaqMan ${ }^{\mathrm{TM}}$ quantitative PCR (qPCR). The 16S rRNA transcript quantity was stable outside the host for $6 \mathrm{~d}$ before bacteria survival declined 2 logs $\left(7.9 \times 10^{8} 16 \mathrm{~S}\right.$ rRNA to $2.3 \times 10^{6}$ transcripts), suggesting that ELO can survive independently outside the host organism. The ELO-specific qPCR probe can therefore be used in future field studies of ELO prevalence within the environment and fauna of the Lyme Bay MPA.
\end{abstract}

KEY WORDS: Endozoicomonas-like organism - Pecten maximus - Pathogen shedding · Quantitative PCR $\cdot$ Rickettsiales-like organism

\section{INTRODUCTION}

The king scallop Pecten maximus (L.) fishery is highly valuable, with landings by UK vessels from natural stocks generating $£ 74.1$ (€85.8) million in 2016 (Marine Management Organisation 2017). Conservation of natural stocks is therefore of great economic and ecological interest. To enhance marine ecology, several marine protected areas (MPAs) have been established along the UK coastline. Designated in 2007, the Lyme Bay MPA is the largest area of protected water in the UK (Rees et al. 2010). Since opening, king scallop population surveys have suggested beneficial recuperation of natural stocks, as demon-

*Corresponding author: irene.canocejas@cefas.co.uk strated by greater abundances of juvenile scallops within the MPA in comparison to external populations (Howarth et al. 2015).

However, in June 2013 and May 2014, king scallop mass mortality events were reported in the Lyme Bay MPA (Fish Health Inspectorate [Cefas] pers. corr.), consistent with previous reports in the English Channel (Le Gall et al. 1988, 1991, S. W. Feist unpubl. data). Histopathological examination of scallops taken from stocks undergoing a mortality event has consistently demonstrated aggregations of bacteria within the host gill tissues. Historically, in the absence of molecular analysis, these bacteria have been described as a Rickettsiales-like organism (RLO) (Le Gall et al.

(C) The authors 2019. Open Access under Creative Commons by Attribution Licence. Use, distribution and reproduction are unrestricted. Authors and original publication must be credited. 
1991). However, 16S rRNA sequencing showed $95 \%$ sequence similarity with species within the genus Endozoicomonas (Gammaproteobacteria: Oceanospiralles) and were therefore designated as an Endozoicomonas-like organism (ELO) (Cano et al. 2018).

An Endozoicomonas symbiont isolated from the bivalve mollusc Atrina pectinata has previously been described (Hyun et al. 2014). Genomic analyses suggest Endozoicomonas species exhibit both symbiotic and free-living stages (Neave et al. 2016). This is largely facilitated by significant genomic plasticity allowing generalised environmental and localised host adaptation (Jensen et al. 2010, Neave et al. 2017). Schreiber et al. (2016) previously demonstrated dissemination of facultative symbiotic Endozoicomonas species between ascidian hosts. The propensity of several Endozoicomonas species to exhibit symbiotic and free-living life cycles suggests the king scallop ELO may be capable of survival outside the host environment.

Developments in molecular analysis of environmental DNA (eDNA) have created new ways of identifying the presence of microorganisms in environmental samples, bypassing the need for traditional microbiological cultivation techniques (Dejean et al. 2011). Lafferty \& Ben-Horin (2013) used a quantitative (q)PCR assay for molecular detection of pathogenic Candidatus Xenohaliotis californiensis in seawater samples. These approaches informed our investigation of ELO survival outside the host, in which a novel Taqman ${ }^{\mathrm{TM}}$ probe specific for the king scallop ELO 16S rRNA gene was used to investigate the release and survival of ELO outside the host environment.

\section{MATERIALS AND METHODS}

\subsection{Animal sampling}

Adult king scallops $(\mathrm{n}=45)$ were collected and kindly donated by commercial divers based within the Lyme Bay MPA $\left(50.6-50.8^{\circ} \mathrm{N}, 2.7-2.8^{\circ} \mathrm{W}\right)$. Animals were measured as recommended by Howard et al. (2004), across the diameter of the shell, and were 9-12 cm in width. Samples were collected in September and October 2016 and January and April 2017. Animals were observed for gross pathology, and a full suite of tissues was sampled for histopathology, as previously described (Cano et al. 2018). Epithelial aggregate counts were measured in 3 separate areas of gill section, and the average value was used as a semi-quantitative indicator of ELO infection severity (minimal, $0<\mathrm{x} \leq 2$; high, $2<\mathrm{x} \leq 10$; severe, $10<\mathrm{x}$ ).
For molecular diagnosis, DNA was extracted from $200 \mu \mathrm{l}$ of homogenised gill tissue using an EZ1 DNA tissue kit and BioRobot EZ1 (Qiagen), following the manufacturer's instructions. The presence of ELO was analysed by standard PCR and quantified by qPCR, as described below.

\subsection{ELO survival outside the host}

Five additional naturally infected scallops, collected in January 2017, were placed in 31 static volumes of UV-filtered seawater for $24 \mathrm{~h}$, and then removed. The water was retained, and $50 \mathrm{ml}$ water samples were taken every $24 \mathrm{~h}$ for $8 \mathrm{~d}$, for RNA extraction, except for at $48 \mathrm{~h}$ when sampling was not permitted. The average water temperature during the trial period was $18^{\circ} \mathrm{C}$ $\left( \pm 2^{\circ} \mathrm{C}\right)$. Water samples for RNA extraction were centrifuged at $1789 \times g\left(30 \mathrm{~min}\right.$ at $\left.4^{\circ} \mathrm{C}\right)$. Pelleted material was re-suspended in $1 \mathrm{ml}$ of RLT buffer (Qiagen). The equivalent of $15 \mathrm{ml}$ of seawater, $300 \mu \mathrm{l}$ of suspension, was used for RNA extraction with the EZ1 RNA minikit in a BioRobot EZ1 (Qiagen). Extracted RNA was used for cDNA synthesis in a $20 \mu \mathrm{l}$ reaction containing $1 \mathrm{mM}$ dNTP, $500 \mathrm{ng}$ of random hexamer primers and 200 units M-MLV reverse transcriptase (Promega) at $37^{\circ} \mathrm{C}$ for $1 \mathrm{~h}$. The gene expression of the ELO 16s rRNA gene was analysed by TaqMan ${ }^{\mathrm{TM}} \mathrm{qPCR}$ assay.

\subsection{ELO TaqMan ${ }^{\mathrm{TM}}$ qPCR assays}

A specific TaqMan ${ }^{\mathrm{TM}}$ qPCR assay was designed, targeting the ELO 16S rRNA gene. A unique region within the gene was identified by a multiple sequence alignment against 16S rRNA sequences of the 2 most closely related organisms (Candidatus Endonucleobacter bathymodioli, GenBank accession FM162185.1; and Endozoicomonas montiporae GenBank accession KJ372452.1), as identified by blast-n alignment (Camacho et al. 2009), as well as Ruegeria atlantica (GenBank accession KJ372486.1) and Vibrio vulnificus (GenBank accession HM996968.1), both frequently isolated from marine environmental DNA samples (Schauer et al. 2003, Jones \& Oliver 2009) (Fig. 1).

A primer set showing unique specificity was designed using Primer Express v3.0 (ThermoFisher): ELO-F (5'-CGG ACC TTG CGC TAT CAG A-3'), ELO-R (5'-GGC CTT TAC CCC ACC AAC TAG-3'), and ELO-probe (6FAM-AGC CTG CGT CGG ATTMGB in $3^{\prime}$ ) (predicted melting temperature of $>59^{\circ} \mathrm{C}$ ).

TaqMan $^{\mathrm{TM}}$ assays were performed with $4 \mu \mathrm{l}$ of DNA or reverse-transcribed cDNA on a StepOne- 


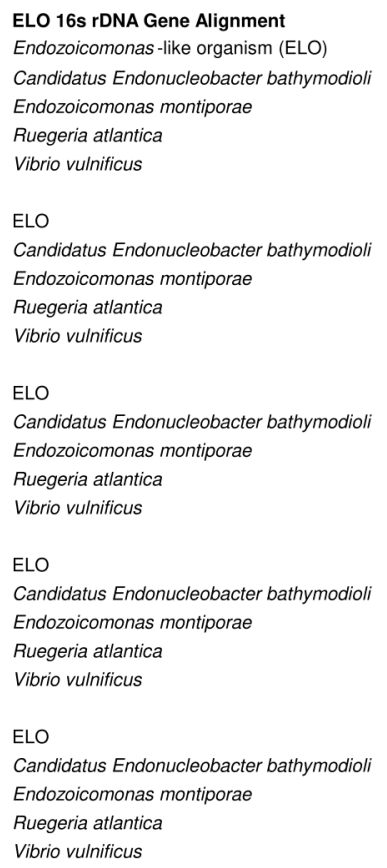

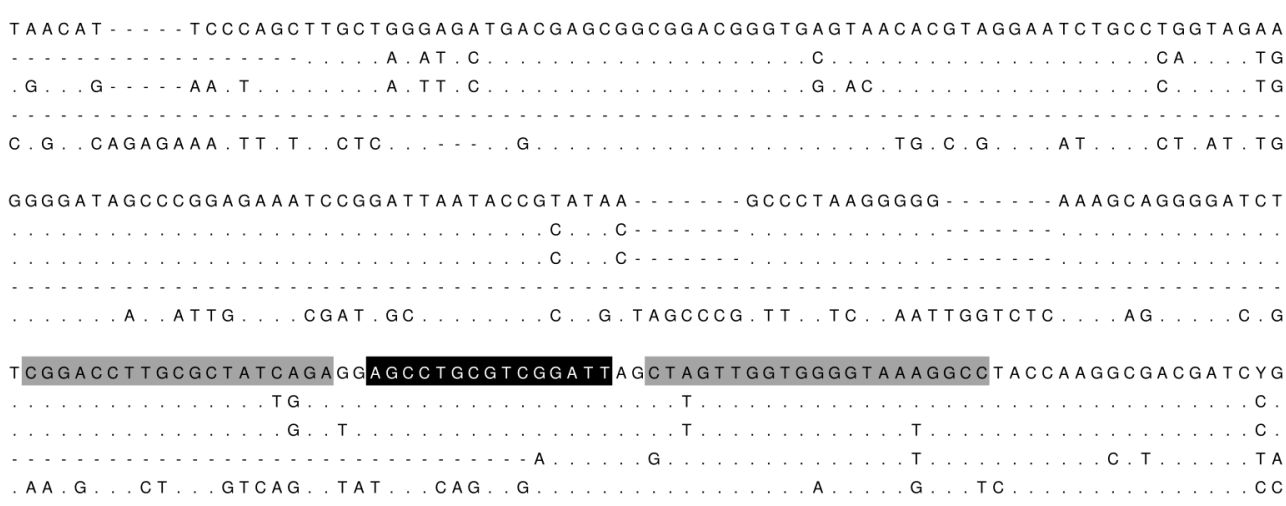

TAGCTGGTCTGAGAGGATGATCAGCCACATTGGGACTGAGACACGGCCCAAACTCCTACGGGAGGCAGCAGTGGGGAA

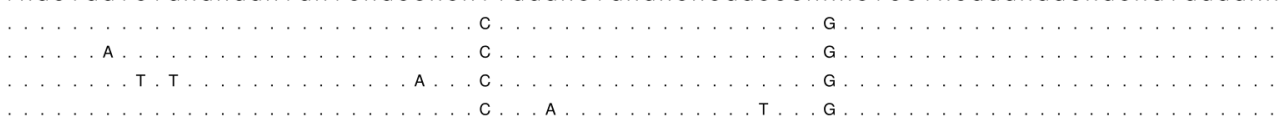

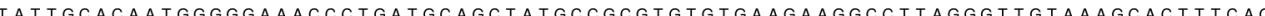

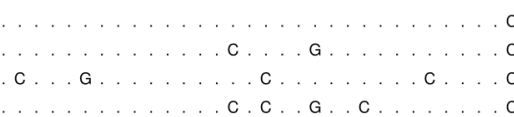

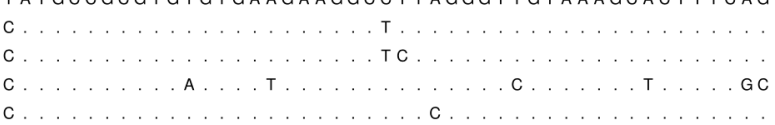

Fig. 1. Endozoicomonas-like organism (ELO) 16S rRNA gene alignment (NCBI accession: KX780138) with Candidatus Endonucleobacter bathymodioli (FM162185.1), Endozoicomonas montiporae (KJ372452.1), Ruegeria atlantica (KJ372486.1), Vibrio vulnificus (HM996968.1). Primer sequences = grey; TaqMan ${ }^{\mathrm{TM}}$ probe $=$ black

Plus $^{\mathrm{TM}}$ Real-Time PCR System (Life Technologies ${ }^{\mathrm{TM}}$ ). The reaction was incubated at $50^{\circ} \mathrm{C}$ for $2 \mathrm{~min}$ and then $95^{\circ} \mathrm{C}$ for $10 \mathrm{~min}$. The reaction then completed 40 cycles, comprising a denaturation step of $95^{\circ} \mathrm{C}$ for $15 \mathrm{~s}$ and an extension step of $60^{\circ} \mathrm{C}$ for $1 \mathrm{~min}$. Each sample was run in duplicate alongside a standard curve produced from a fragment of $749 \mathrm{bp}$ of the scallop ELO 16S rRNA gene, amplified using the universal prokaryote $16 \mathrm{~S}$ primer FD1 (5'-AGA GTT TGA TCC TGG CTC AG-3') (Weisburg et al. 1991) and the ELO diagnostic primer IMC-R (5'-CTT CGT TAC CAG AAA CTC TAA GGT C-3') (Cano et al. 2018).

The fragment was cloned into a pGem-T Easy plasmid vector (Promega), following standard protocols. Plasmid concentration was measured using a NanoDrop ND-1000 spectrophotometer (ThermoScientific), and serially diluted in molecular-grade water. Quantification of ELO release was measured by cycle threshold $(\mathrm{Ct})$ values of a qPCR reaction. The regression analysis of the standard curves gave an average slope of $-2.809, \mathrm{R}^{2}=0.97$ and a PCR efficiency of $127 \%$ (Fig. A1 in the Appendix).

\subsection{Statistical analyses}

Infection severity was compared to identify any significant difference in bacterial abundance be- tween the 4 sample groups, using a non-parametric Kruskal-Wallis test (95\% significance). The volume of ELO shed by animals in the second trial was analysed by linear modelling with regression analysis (95\% significance). Statistical analyses were conducted in RStudio V1.1.383 (RStudio Team 2018).

\section{RESULTS}

\subsection{Seasonal survey of the Lyme Bay MPA scallop population}

The Lyme Bay MPA scallop population was studied by molecular and histological analyses. All animals, except 1 (out of 45), showed large bacterial aggregates within gill epithelial tissue. Two colony types of Gram-negative bacteria, Type I and II, were observed as previously described in Lyme Bay MPA scallops (Cano et al. 2018) (Fig. 2A). Intensity of the infection ranged from 'minimal' to 'severe' (see Section 2.1) (Table 1). In some heavily infected tissues, there were examples of aggregate ruptures (Fig. 2A) and subsequent release of bacteria into the interlamellar space (Fig. 2B). All gill epithelial tissue DNA extractions were positive for the ELO 16S rRNA gene. However, no significant difference in ELO load was identified between the 4 sample groups ( $\mathrm{p}=$ 

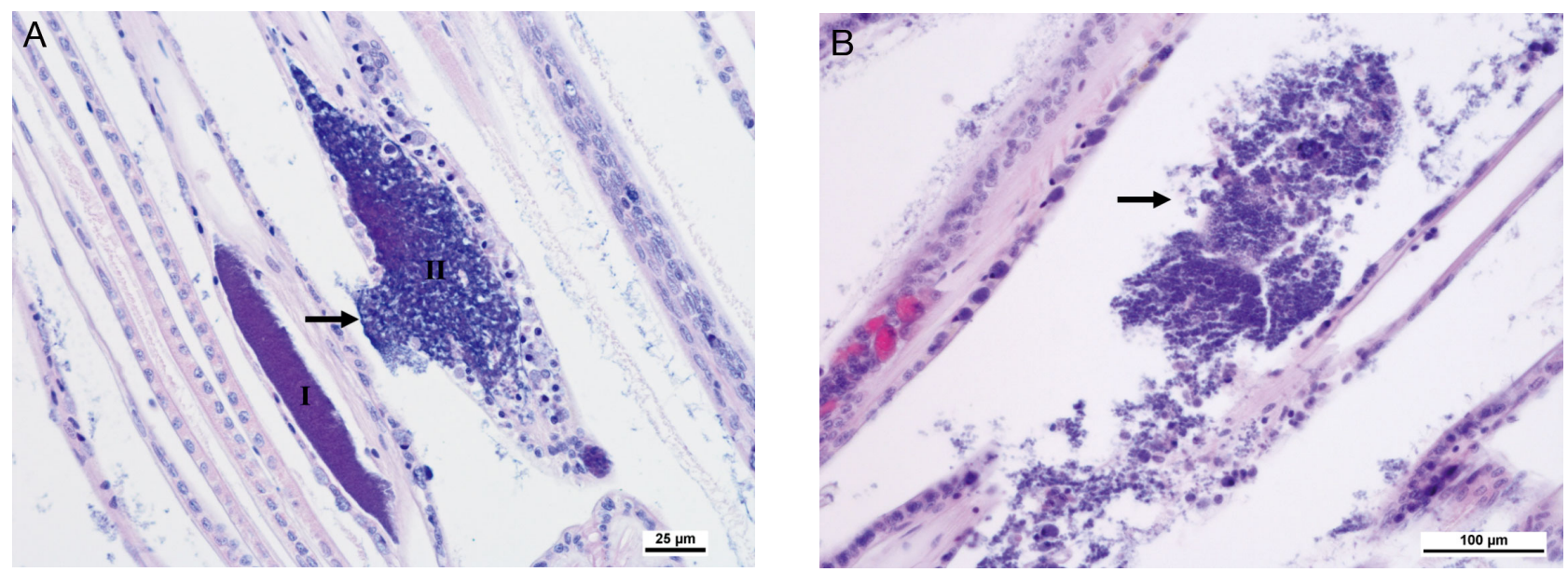

Fig. 2. (A) H\&E staining of Type I and Type II ELO aggregates infecting gill epithelial tissue in king scallop. Rupturing (arrow) is evident in the Type II epithelial aggregate. (B) ELO cells (arrow) in interlamellar space

0.143; non-parametric Kruskal-Wallis test), by qPCR (Fig. 3). Other parasites were occasionally identified within histological sections at very low numbers and prevalence across the sampling groups (Table 1).

\subsection{Detection of ELO shed by naturally infected scallops into the water column}

Water samples taken after $48 \mathrm{~h}$ from the static containers holding naturally infected scallops tested positive for the ELO 16S rRNA gene by PCR, at a

Table 1. Summary of the Lyme Bay MPA survey of king scallops. Epithelial aggregate counts were measured in 3 separate areas of histological tissue and averaged as a semi-quantitative indicator of ELO infection severity (see Section 2.1)

\begin{tabular}{|c|c|c|c|c|}
\hline & \multicolumn{2}{|c|}{$-2016-$} & \multicolumn{2}{|c|}{-2017} \\
\hline & Sep & Oct & Jan & Apr \\
\hline Gross pathology & $(\mathrm{n}=10)$ & $(\mathrm{n}=10)$ & $(\mathrm{n}=10)$ & $(\mathrm{n}=15)$ \\
\hline Pale gills & 0 & 1 & 2 & 1 \\
\hline Gill damage & 0 & 1 & 0 & 1 \\
\hline Histology & $(\mathrm{n}=10)$ & $(\mathrm{n}=10)$ & $(\mathrm{n}=10)$ & $(n=15)$ \\
\hline \multicolumn{5}{|l|}{ ELO } \\
\hline Absent & 0 & 1 & 0 & 0 \\
\hline Minimal & 1 & 2 & 1 & 3 \\
\hline High & 5 & 3 & 5 & 9 \\
\hline Severe & 4 & 4 & 4 & 2 \\
\hline Coccidian & 1 & 0 & 1 & 0 \\
\hline Trichodina & 1 & 1 & 0 & 0 \\
\hline $\begin{array}{l}\text { Digestive gland } \\
\text { parasite }\end{array}$ & 0 & 0 & 0 & 4 \\
\hline Parasitic worm & 0 & 1 & 0 & 1 \\
\hline Molecular & $(\mathrm{n}=10)$ & $(\mathrm{n}=10)$ & $(\mathrm{n}=10)$ & $(\mathrm{n}=10)$ \\
\hline ELO PCR & 10 & 10 & 10 & 10 \\
\hline
\end{tabular}

minimum water sample volume of $300 \mu \mathrm{l}(0.001 \%)$ (Fig. 4). ELO shedding was confirmed in all 5 inhabited containers by PCR with DNA extractions taken from $1.5 \mathrm{ml}$ samples $(0.005 \%)$ of total water.

\subsection{Survival of ELO outside the host animal}

The ELO 16S rRNA transcripts were detected from water samples taken on Days 1 to 8, after animals were removed from the static holding containers. Overall number of $16 \mathrm{~S}$ rRNA transcripts decreased 2 logs $\left(7.9 \times 10^{8}\right.$ to $2.3 \times 10^{6}$ transcripts $)$ over the $8 \mathrm{~d}$

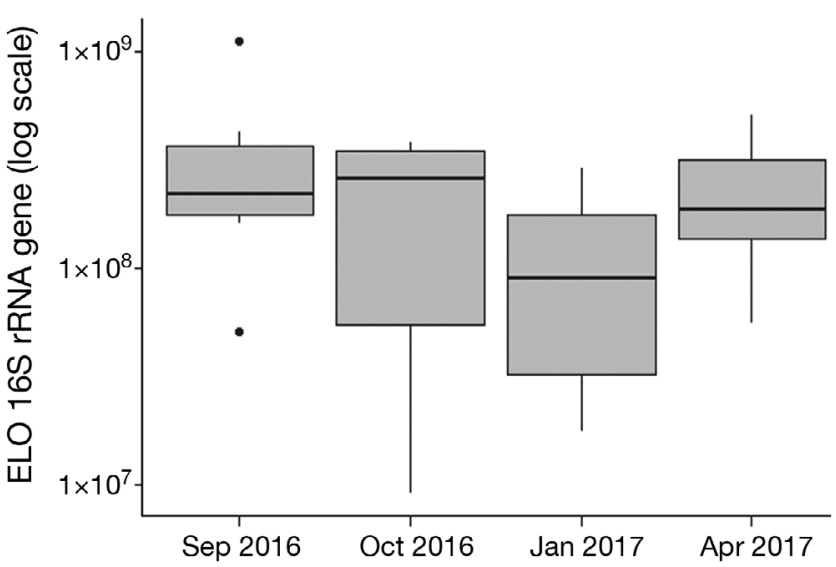

Fig. 3. Seasonal variation in ELO infection outside of known mortality events. Infection level based on the number of copies of the ELO 16S rRNA gene. Box plots indicate 4 sample groups $(\mathrm{n}=10)$; line: median; box: interquartile range (IQR); whiskers: max./min. value $\leq 1.5 \times$ IQR above/below box; dots: outliers. No significant difference was identified across the 4 seasons ( $p=0.143$; non-parametric KruskalWallis test) 


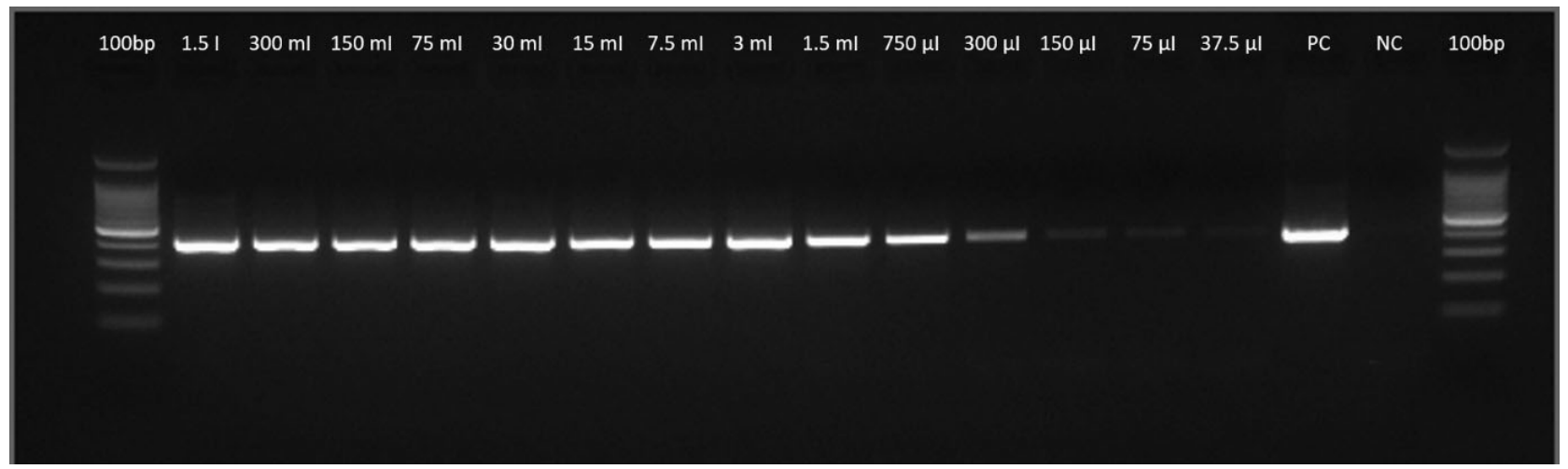

Fig. 4. Detection of the ELO 16S rRNA gene in the water column. Agarose gel showing an amplified PCR band of 407 bp corresponding to a fragment of the ELO 16S rRNA gene in water samples ranging from 1.51 to $37.5 \mu \mathrm{l}$. First and last rows = $100 \mathrm{bp}$ ladder. PC: positive control (DNA extracted from known infected host gill epithelial tissue); NC: negative control (moleculargrade water)

period. A linear model was used to investigate significant differences in ELO 16s rRNA quantity between the sampling days. A significant difference was identified between the control group (Day 1) and the remaining sampling days $\left(F_{6,27}=10.14, \mathrm{p}<0.0001\right.$, adjusted $R^{2}=0.6243$ ). No significant differences in the volume of ELO present were seen between the water samples from Day 1 and Days 3 to $6(\mathrm{p}=0.108$, $0.962,0.572,0.211)$. At $7 \mathrm{~d}$, the average number of copies across the 5 holding containers dropped, with a significant difference in the number of transcripts between Days 1 and $7(\mathrm{p}=0.020)$ and Days 1 and 8 $(\mathrm{p}=0.018$; Fig. 5).

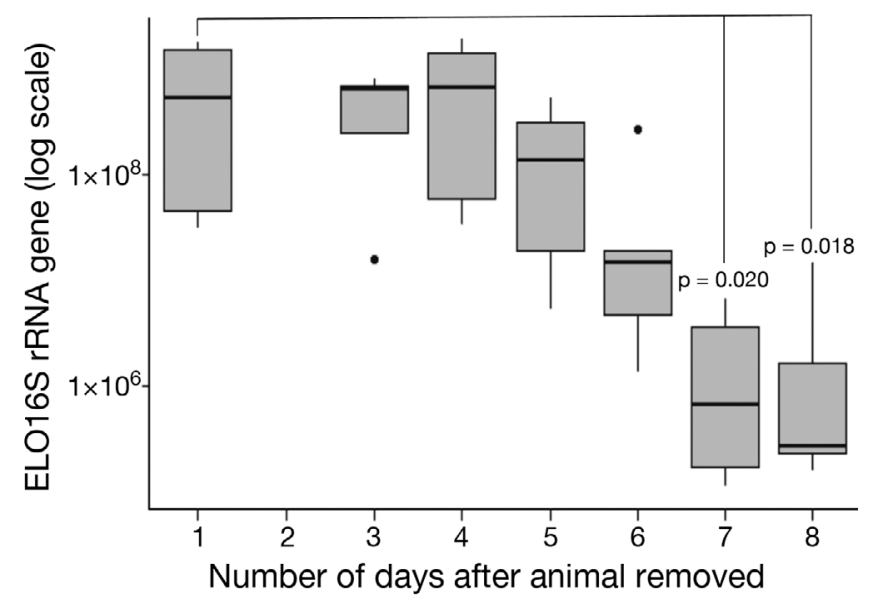

Fig. 5. Number of copies of transcripts of the ELO 16S rRNA gene in RNA extracted from $15 \mathrm{ml}$ of seawater. Number of transcripts quantified by TaqMan ${ }^{\mathrm{TM}}$ qPCR. Range in copy number across 5 animals shown over the $8 \mathrm{~d}$ sample period after the animal was removed. Samples were not collected on Day 2. Brackets with specific p-values connect data sets demonstrating significant differences from Day 1 ( $p<0.05$ by regression analysis). Box plot features as in Fig. 3

\section{DISCUSSION}

We have reported the development of a TaqMan ${ }^{\mathrm{TM}}$ qPCR assay for the king scallop ELO 16S rRNA gene. This assay was used in quantifying the bacterial load in animals within the Lyme Bay MPA, outside of reported mortality events. Previous mass mortalities were recorded during the summer months, when average water temperatures reached $16.8^{\circ} \mathrm{C}$ (Cano et al. 2018). It was therefore hypothesised that water temperature could affect ELO infection severity, with the inference that higher temperatures facilitate faster bacterial growth and greater transmission (Braid et al. 2005). This is supported by previous studies of RLO-associated mortality events in marine animals during periods of increased seawater temperature (Friedman \& Finley 2003). However, samples taken throughout a 1 yr survey demonstrated that severe levels of ELO infection are highly prevalent in the king scallop population outside of mortality events, suggesting that both environmental and biotic factors likely influence mortality events.

Animals sampled between September 2016 and April 2017 showed no significant difference in host infection severity, by qPCR. The consistently high quantity of ELO 16S rRNA gene transcripts identified by molecular analysis across the 4 sample groups correlated with the predominantly 'high' and 'severe' levels of infection observed in host animal histopathology. The ubiquity of ELO infection in sampled animals therefore raised questions about the dynamics of transmission of the bacteria between host animals. While terrestrial intracellular Rickettsiales infections are limited to vector-based transmission (Merhej \& Raoult 2011), the marine environment pro- 
vides a substrate allowing transmission of intracellular pathogens of marine animals (Braid et al. 2005, Lafferty \& Ben-Horin 2013, Schreiber et al. 2016).

Under controlled experimental conditions, the release of large quantities of transcripts of the ELO 16S rRNA gene have been demonstrated from naturally infected king scallops into the surrounding water body. The identification of actively transcribed housekeeping mRNA transcripts suggests that the ELO is viable outside the host environment. By this measurement, the bacteria appear capable of surviving for approximately $6 \mathrm{~d}$ before a significant decline in mRNA expression is observed.

The consistently high prevalence of the ELO in wild king scallop populations, alongside the evidence of large amounts of ELO shedding from host animals into the water column, suggests that the ELO may be able to survive as a free-living organism for periods long enough to permit horizontal transmission. A similar time period of environmental survival was identified for Piscirickettsia salmonis, the causative agent of piscirickettsiosis in salmonids. Fryer \& Lannan (1996) demonstrated that $P$. salmonis can retain virulence for a maximum of $14 \mathrm{~d}$ in highsalinity environments. This has been experimentally demonstrated to facilitate horizontal transmission between hosts via oral routes or the gill tissue (Cvitanich et al. 1991), a transmission route also observed in the movement of the intracellular RLO Candidatus Xenohaliotis californiensis between a marine molluscan host, Haliotis rufescens (Braid et al. 2005).

The focal point of ELO infection in king scallops is the gill tissue, where bacterial aggregates were observed in all adults. It is therefore possible the ELO follows a similar transmission route, with bacteria being released from the host gill epithelial tissue into the surrounding water where it is filtered into a new host animal.

The spread of RLOs from fish gill epithelial tissue is hypothesised to occur when physical barriers of the gills and skin are breached by the bacterium, allowing environmental release (Lloyd et al. 2011). The disrupted gill tissue observed in histology suggests that aggregation of ELO bacteria within the epithelial tissue causes similar mechanical disruption, which may allow release of large numbers of bacteria from the host tissue into the surrounding water column (Le Gall et al. 1988, Cano et al. 2018).

Horizontal transmission of the ELO between host animals must be confirmed by a cohabitation challenge. However, the high prevalence of the ELO in MPA king scallop populations has limited the identification of naïve organisms, preventing a challenge model. If horizontal transmission is occurring through an environmental transmission route, this would permit infection of further host animals. The Lyme Bay MPA contains a rich variety of molluscs, crustaceans and fish (Rees et al. 2010), all of which could support ELO infection. Further surveys are needed to better understand ELO ecology within the Lyme Bay MPA fauna. Likewise, it is currently unclear whether the high prevalence of bacteria recorded in Lyme Bay scallop stocks is the result of increased population density within the designated MPA (Howarth et al. 2015), However, surveying of wild populations outside the Lyme Bay MPA is required before any conclusive associations can be made.

Acknowledgements. We thank John Worswick for generously providing scallops throughout the investigation; Matthew Green, Robert McFarling and Ander Urrutia for help with histology; and Mickael Teixeira Alves for statistical support. Funding from the UK Department for Environment, Food and Rural Affairs (DEFRA) contracts F1172 and FB002A (to S.W.F.) and the EU-funded project Vivaldi (H2020 program, no. 678589) is gratefully acknowledged.

\section{LITERATURE CITED}

Braid BA, Moore JD, Robbins TT, Hedrick RP, Tjeerdema RS, Friedman CS (2005) Health and survival of red abalone, Haliotis rufescens, under varying temperature, food supply, and exposure to the agent of withering syndrome. J Invertebr Pathol 89:219-231

Camacho C, Coulouris G, Avagyan V, Ma N, Papadopoulos J, Bealer K, Madden TL (2009) BLAST+: architecture and applications. BMC Bioinformatics 10:421

* Cano I, van Aerle R, Ross S, Verney-Jeffreys D and others (2018) Molecular characterization of an Endozoicomonaslike organism causing infection in the king scallop Pecten maximus L. J. Appl Environ Microbiol 84:e00952-17

Cvitanich JD, Garate O, Smith CE (1991) The isolation of a rickettsia-like organism causing disease and mortality in Chilean salmonids and its confirmation by Koch's postulate. J Fish Dis 33:849-858

Dejean T, Valentini A, Duparc A, Pellier-Cuit S, Pompanon F, Taberlet P, Miaud C (2011) Persistence of environmental DNA in freshwater ecosystems. PLOS ONE 6:e23398

Friedman CS, Finley CA (2003) Evidence for an anthropogenic introduction of 'Candidatus Xenohaliotis californiensis', the etiological agent of withering syndrome, into northern California abalone populations via conservation efforts. Can J Fish Aquat Sci 60:1424-1431

*Fryer JL, Lannan CN (1996) Rickettsial infections of fish. Annu Rev Fish Dis 6:3-13

* Howard DW, Lewis EJ, Keller BJ, Smith CS (2004) Histological techniques for marine bivalve mollusks and crustaceans. NOAA Tech Memo NOS NCCOS 5. http:// aquaticcommons.org/14949/1/nos_nccos_5.pdf

*Howarth L, Roberts C, Hawkins J, Steadman D, BeukersStewart B (2015) Effects of ecosystem protection on scallop populations within a community-led temperate marine reserve. Mar Biol 162:823-840 
Hyun DW, Shin NR, Kim MS, Oh SJ, Kim PS, Whon TW, Bae JW (2014) Endozoicomonas atrinae sp. nov., isolated from the intestine of a comb pen shell Atrina pectinata. Int J Syst Evol Microbiol 64:2312-2318

Jensen S, Duperron S, Birkeland NK, Hovland M (2010) Intracellular Oceanospirillales bacteria inhabit gills of Acesta bivalves. FEMS Microbiol Ecol 74:523-533

Jones MK, Oliver JD (2009) Vibrio vulnifius: disease and pathogenesis. Infect Immun 77:1723-1733

Lafferty KD, Ben-Horin T (2013) Abalone farm discharges the withering syndrome pathogen into the wild. Front Microbiol 4:373

Le Gall G, Chagot D, Mialhe E, Grizel H (1988) Branchial Rickettsiales-like infection associated with a mass mortality of sea scallop Pecten maximus. Dis Aquat Org 4: 229-232

Le Gall G, Mialhe E, Chagot D, Grizel H (1991) Epizootiological study of rickettsiosis of the Saint-Jacques scallop Pecten maximus. Dis Aquat Org 10:139-145

Lloyd SJ, La Patra SE, Snekvik KR, Cain KD, Call DR (2011) Quantitative PCR demonstrates a positive correlation between a Rickettsia-like organism and severity of strawberry disease lesions in rainbow trout, Oncorhynchus mykiss (Walbaum). J Fish Dis 34:701-709

Marine Management Organisation (2017) UK sea fisheries statistics 2016. National Statistics, London

Merhej V, Raoult D (2011) Rickettsial evolution in the light of comparative genomics. Biol Rev Camb Philos Soc 86: 379-405

Neave MJ, Apprill A, Ferrier-Pagès C, Voolstra CR (2016) Diversity and function of prevalent symbiotic marine bacteria in the genus Endozoicomonas. Appl Microbiol Biotechnol 100:8315-8324

Neave MJ, Michell CT, Apprill A, Voolstra CR (2017) Endozoicomonas genomes reveal functional adaptation and plasticity in bacterial strains symbiotically associated with diverse marine hosts. Sci Rep 7:40579

Rees SE, Attrill MJ, Austen MC, Mangi SC, Richards JP, Rodwell LD (2010) Is there a win-win scenario for marine nature conservation? A case study of Lyme Bay, England. Ocean Coast Manag 53:135-145

RStudio Team (2018) RStudio: integrated development for R. RStudio, Boston, MA

* Schauer M, Balagué V, Pedrós-Alió C, Massana R (2003) Seasonal changes in the taxonomic composition of bacterioplankton in a coastal oligotrophic system. Aquat Microb Ecol 31:163-174

Schreiber L, Kjeldsen KU, Funch P, Jensen J, Obst M, López-Legentil S, Schramm A (2016) Endozoicomonas are specific, facultative symbionts of sea squirts. Front Microbiol 7:1042

*Weisburg WG, Barns SM, Pelletier DA, Lane DJ (1991) 16s Ribosomal DNA amplification for phylogenetic study. J Bacteriol 173:697-703

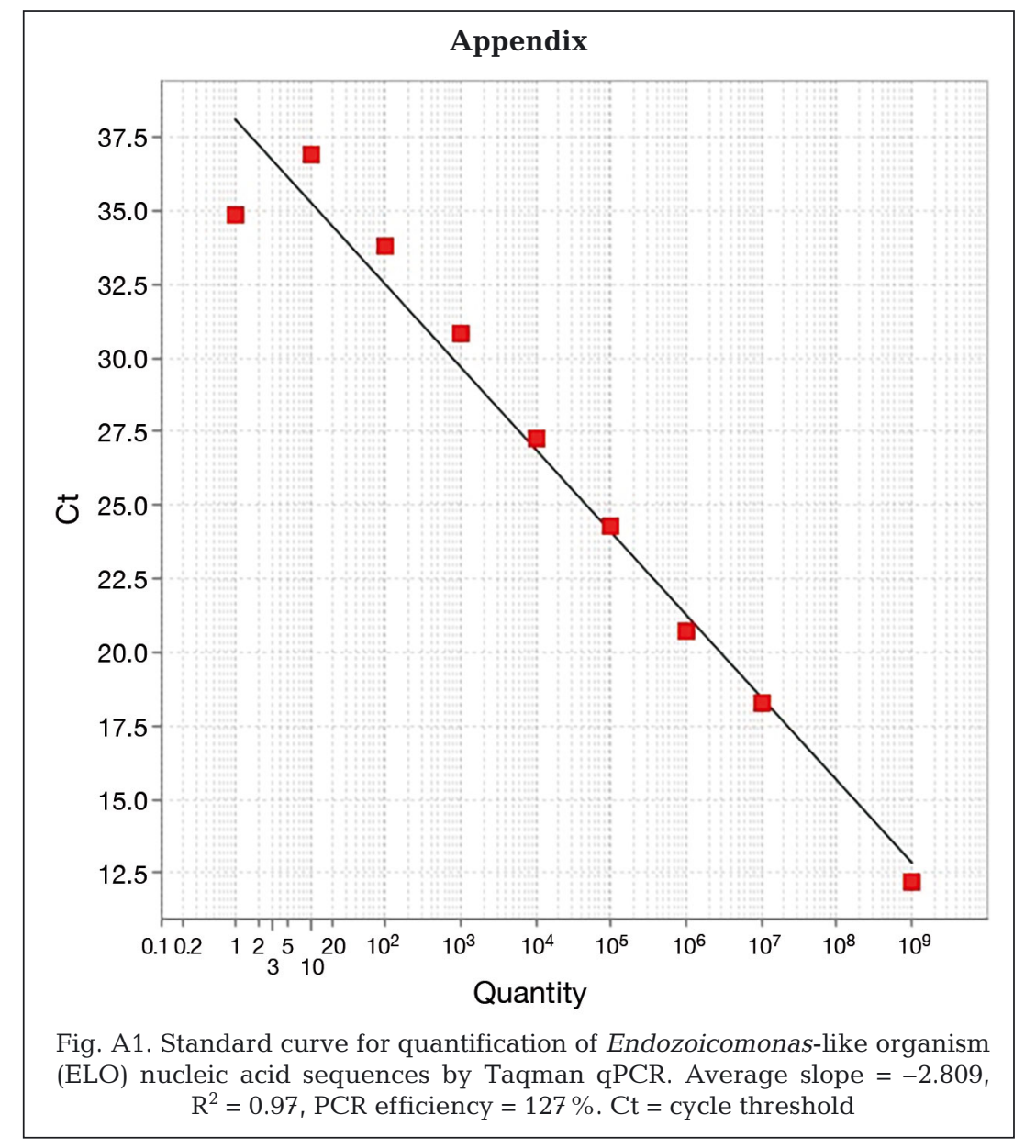

